\title{
Privatization Through IPO as a Tool of Attracting FDI: The Case of Ukraine
}

\author{
Kornieieva Iuliia \\ Department of Macroeconomic Regulation \& International Economic Relations, Academy of Financial Management, Kyiv, Ukraine \\ Email address: \\ korneevaj@ukr.net

\section{To cite this article:} \\ Kornieieva Iuliia. Privatization Through IPO as a Tool of Attracting FDI: The Case of Ukraine. Journal of Political Science and \\ International Relations. Vol. 1, No. 1, 2018, pp. 12-19. doi: 10.11648/j.jpsir.20180101.12
}

Received: November 4, 2017; Accepted: November 20, 2017; Published: December 24, 2017

\begin{abstract}
This article analyses the use Initial Public Offering (IPO) as one of the priority ways of privatization of large state-owned enterprises, carried out in order to attract long-term investment resources and improve the level of corporate governance in Ukraine. Lack of investment resources in Ukraine causes the need of entering foreign capital markets and attraction foreign investors for privatization processes. The insufficient development of institutional conditions in countries with transformational economies is seen as an obstacle to the introduction of an effective regulation system of privatization processes. The article considers the specific to Ukrainian state-owned company's problems of conducting IPO. Such enterprises do not meet the requirements of listing of leading stock exchanges, and therefore require the assistance of financial intermediaries and international donors in the organization of transparent privatization through the sale of shares in the stock markets. The author analysed the advantages of cooperation of Ukrainian state-owned companies with underwriters under the "firm commitment" scheme and risks in case of receiving services from a financial intermediary under the "best efforts" scheme. The article deals with guarantee mechanisms of support of privatization processes aimed at attracting foreign investments. It is emphasized that provision of additional guarantees will contribute to the inflow of capital. The author proposes a mechanism for the provision of privatization compensatory guarantees to the underwriters by international financial organizations for the successful initial public offering of shares of state-owned companies which are subject to privatization in Ukraine.
\end{abstract}

Keywords: State-Owned Enterprise, Privatization, Stock Exchange, Listing, Share, Privatization Compensatory Guarantees

\section{Introduction}

There is a tendency towards the transformation of a number of state-owned enterprises operating in a competitive market segment into state-controlled joint-stock companies. The main purpose of such transformation processes is to increase the efficiency of the performance of state-owned companies and to attract investment from the new owner to the privatized object. Mixed ownership allows the government to share risks with private investors. Nowadays the "mixed ownership" model presented by listed Stateowned Enterprises (SOEs) is spreading around the world; and injection of private capital into SOEs can improve their management and expose the enterprises to badly needed market discipline [1]. For sure, the mixed ownership is not a guarantee of an increase in the efficiency of an enterprise. And as in the case of China it won't change the relationship between firms and the state and cannot lead to introduction of new model of behaviour in the Chinese economy [2]. But due to the sale of shares through a public offering mechanism there are new opportunities to attract financial resources for state enterprise in case of partial privatization. The stock market allows using one of the most effective mechanisms of attracting, distributing and redistributing investment resources. The analysis of the effectiveness of the privatization mechanism in the context of structural changes on financial markets, which take place under the influence of modernization of the institutional structure of international finances, becomes especially relevant. Taking into account the best international experience of transferring the state ownership into a private and conceptual analysis of the feasibility of privatization over a period of time will help to identify the relevant elements of the public finance management strategy that would contribute to improving the relevant system in Ukraine. 
The complexities that arose during the privatization of stateowned enterprises in Ukraine are primarily due to the existence of not transparent mechanisms for the transfer of state property to the private sector. However, as the practice of foreign countries shows, privatization can contribute to the inflow of Foreign Direct Investment (FDI) to the country, attracting advanced technologies together with capital. The issue of attracting investment resources is closely depends on the investment climate in the country. If in some country there is a possibility of expropriation of privatized objects due to the lack of clear norms and rules and as a result of a change in the alignment of political forces, it will affect the expectations of investors and reduce their interest in proposed objects. Such an image will have a very negative effect on the directions of capital flows and reduce inflows of investments. In this context it is important to emphasize the importance of using lawful methods of converting private property into public property which are subject of government control and strict regulations [3]. It is clear that in case of not defending private investors' property rights we can't speak about possibility of attraction more investment into the country. The corruption is also a serious obstacle on the way of transforming public property into private [3]. In Europe some countries also have problems with privatization processes due to the loose of transparency and accountability because of corruption and conflicts of interest that occur. Particularly in Greece, state assets have often been sold for prices far below their true market value. But still the authorities of the International Monetary Fund (IMF), the European Central Bank (ECB) and the European Commission (EC) claim that private ownership will make companies more cost effective and competitive and that the public will benefit from lower prices and better service, emphasising that privatisation of public companies contributes to the reduction of public debt, as well as to the reduction of subsidies, other transfers or state guarantees to state-owned enterprises and has a great potential of attracting foreign direct investment [4].

Taking into account the prospects for further economic development of Ukraine in the context of integration into the European Union (EU), it is necessary to introduce modern forms and methods of attracting long-term investments into the real sector of the economy. Privatization in countries with a transformational economy requires new, non-standard solutions that can be a basis and incentives for implementation of reforms. Such incentives can be a driving force behind structural change and economic growth in the medium and long term.

\section{Literature Review}

P. Krugman notes that the regulatory system should be based on the combination of state regulation with free markets. At the same time scientist is denying blind intervention into the economic processes. Krugman's "Positive theory" envisages the creation of such conditions that would contribute to development of an enterprise, industry, region, etc., but, as the author points out, these are not ideal conditions, but incentives [5]. P. Krugman wrote that globalization intensifies the concentration of capital, promotes the creation of financial centres and their growth [6]. In the context of this statement, it becomes clear that it is difficult for transformation economies, as well as for new market economies to compete for capital and for a place in global trade flows. Accordingly, incentives to facilitate Ukraine's access to foreign capital are essential. In this context, the process of going public and entering of Ukrainian state-owned enterprises on international capital markets is clear and understandable. To solve these tasks we are talking about the need of creation some incentives for countries with transformational economies. Such incentives wouldn't violate the market equilibrium, but at the same time can simplify the privatization mechanism taking into account the existing problems concerning high levels of corruption and shadow economy.

One of the main conclusions of the Shapiro-Willig model is the importance of introducing clear and transparent mechanisms for state regulation of privatization processes based on timely and full access to financial information of a private company [7]. Privatization of enterprises through the Initial Public Offering (IPO) mechanism will fully meet these requirements. Due to the benefits which politicians and government officials receive from the work of state-owned companies, the term "reluctant privatization" appeared in the scientific literature at the beginning of the 21st century [8]. Swee-Sum Lam, Ruth Seow-Kuan Tan, Glenn Tsao-Min Wee in their research explain the undervaluation of the price of the shares of the initial placement of the privatized company due to the political risk, and not to the risk of asymmetry of information, because the government usually tries to leave a large block of shares in public property [9]. R. Fisman and Faccio Mara, Ronald W. Masulis, John J. McConnell emphasize that political connections increase firm value [10], [11]. Villalonga B. proves that the efficiency and effectiveness of privatization are strongly influenced by institutional and organizational factors, emphasizing that the sale of a stateowned enterprise to a foreign investor significantly improves the final result of privatization [12]. Recent studies show that the benefits from listing of state-owned enterprises can only be reaped in case of developed stock markets and sufficiently functional legal system that will ensure protection of the rights of investors, especially of minority shareholders [13].

Despite the large number of studies devoted to analyzing the peculiarities and effectiveness of the IPO mechanism of securities in stock exchanges, insufficiently highlighted remains the issue of IPO for companies that are in state ownership and do not meet the requirements for listing of leading stock exchanges, and therefore need the assistance of international donors in the organization of transparent privatization through the sale of shares in the stock market.

\section{Discussions}

\subsection{Stock Market as the Platform for FDI Attraction During Privatization: Possibilities for Ukraine}

An effective privatization regulation system involves the 
presence of some obligatory elements. These include the appropriate level of technical and informational support for the conduct and maintenance of privatization agreements, which requires the appropriate infrastructure, highly skilled professionals and legally established consistent rules and regulations. An important factor in improving the efficiency of public finance management for countries with high levels of corruption is professional external control over the valuation of privatization objects. The role of financial intermediaries in these processes should be tangible. Validity system of valuation of privatized assets should be made in order to prevent the underestimation of the value of objects, in order to prevent losses to the state budget.

Privatization in Ukraine can become one of the main ways of attracting long-term foreign investments. In order to increase the confidence of foreign investors in the Ukrainian market, privatization (full or partial) of state-owned enterprises should be conducted at an open auction, and all information about the work of the enterprise should be provided to all potential buyers. The reform of the state-owned sector requires the use of such models that would contribute to sustainable economic growth in the long run. The development of hightech and export-oriented industries requires significant investments. The inflow of FDI to the country's economy is an extremely important factor contributing to sustainable economic growth. After all, along with capital, the country adopts advanced world technologies, which contributes significantly to the restructuring of the economy, provides for the modernization of out-dated production, and guarantees the transition to innovative development models.

The Letter of Intent on Ukraine's commitment to policy implementation and the fulfillment of the objectives of the economic program supported under the IMF agreement issued on March 2, 2017, identifies a large and inefficient public sector as one of the significant challenges to the implementation of reforms and economic growth in Ukraine. In accordance with the commitments, Ukraine should carry out a reform of state-owned enterprises, which includes: supervision of fiscal risks of state-owned enterprises, reform of state-owned enterprises, liquidation of non-functioning state-owned enterprises and privatization. The letter also emphasizes that Ukraine has limited achievements in the privatization of large state-owned enterprises [14].

According to the information of Ministry of Economic Development and Trade of Ukraine, as of July 2017, in state ownership are 3444 state-owned objects, of which $15(69 \%$ of all assets) will be attributed to strategic enterprises Ukrzaliznytsya, Ukrposhta, Naftogaz, Yuzhnoye State Design Office, Antonov, Khartron, Yuzhmash, PLANT 410 CA, Kharkiv State Aviation Production Enterprise, Administration of Seaports, Energoatom, Ukrhydroenerho, Ukrenergo, Eastern Mining and Processing Plant and Ukrchimtransamiak). 893 enterprises are planned to be privatized, the share of objects for privatization is $11.1 \%$ of all state assets [15]. The results of the IMF experts' analysis of financial and nonfinancial assets show that the size of the state property portfolio in Ukraine at the beginning of 2014 was approximately $60 \%$ of Gross domestic product (GDP) or 72 billion of United States dollars (US dollars), with financial assets accounting for about $18 \%$ of GDP or 22 billion of US dollars, nonfinancial assets accounted for about $42 \%$ of GDP or 50 billion of US dollars [16]. It should also be noted that there is no consolidated public information on the size and value of the state property portfolio in Ukraine.

The detection of a significant negative impact of state property on the state budget and the actual suspension of privatization processes since 2009 is important conclusion of the IMF Report on the provision of technical assistance to Ukraine. The management of state property in Ukraine is decentralized and fragmented with a wide range of management subjects with different responsibilities, which are often duplicated or contradictory to one another, due to the existence of a complex and often contradictory regulatory framework. This prevents transparency and does not allow for the privatization programs recovery in Ukraine [16].

Budget revenues from privatization are extremely important for Ukraine today. The state budget revenues from privatization in 2016 amounted to 188.9 million of Ukrainian hryvnia (UAH) from the planned UAH 17.1 billion, which according to the Law "On the State Budget of Ukraine" The State Property Fund of Ukraine (SPFU) was to be sent to the budget [17]. During 2015, privatization of the state budget amounted to UAH 151.481 million, although the Law of Ukraine "On the State Budget of Ukraine for 2015" set up the State Property Fund a task to receive funds in the amount of UAH 17 billion [18]. These indicators characterize the imperfection of privatization processes in Ukraine. Below in table 1 we present statistics that show the dynamics of real budget revenues from privatization and volumes of planned indicators in Ukraine.

Table 1. Planned and real indicators of state budget revenues from privatization of state property for 2010-2016.

\begin{tabular}{llll}
\hline year & $\begin{array}{l}\text { Revenue from the privatization of state property } \\
\text { and other income directly related to the } \\
\text { privatization process (billion, UAH) }\end{array}$ & $\begin{array}{l}\text { The planned revenue (in accordance with } \\
\text { the Law of Ukraine "On the State Budget of } \\
\text { Ukraine"), UAH billion. }\end{array}$ & $\begin{array}{l}\text { In\% of the annual planned } \\
\text { task }\end{array}$ \\
\hline 2010 & 8,5 & 10 & $85 \%$ \\
2011 & 11,480 & 10 & $114,8 \%$ \\
2012 & 6,765 & 10 & $67,65 \%$ \\
2013 & 1,4799 & 10,9 & $13,57 \%$ \\
2014 & 0,447 & 19,4 & $2,4 \%$ \\
2015 & 0,151481 & 17 & $0,9 \%$ \\
2016 & 0,331 & 17,1 & $1,93 \%$ \\
\hline
\end{tabular}

Source: compiled by author based on [19]. 
Failure to implement the budget in terms of privatization proceeds is to some extent characterized by the imperfection of the privatization process regulation system in Ukraine. Undoubtedly there are quite a lot of reasons that hinder privatization. However, the potential of attracting foreign investors on international financial markets should be taken into account when placing shares of state-owned enterprises on foreign stock exchanges. In the context of this research, we will consider the privatization of state-owned enterprises as a mechanism for attracting long-term investments. Currently in Ukraine there has been a sharp shortage of investment resources, which makes enterprises more actively use stock market instruments to attract investment. At the same time, the overall situation in Ukraine for long-term investment remains unfavorable. The development of recommendations for attracting long-term investments as a result of the privatization of state-owned enterprises is extremely important for the socio-economic development of Ukraine. At the same time, it will contribute to not only the engagement of financial resources, but also arrival of advanced technologies and management experience. Improvement of the mechanism of privatization requires, first of all, the introduction of elements that will ensure planning, publicity and control in this area. A prerequisite for the introduction of an effective privatization regulation system is the transparency and reasonableness of political decisions regarding the privatization of key enterprises of the national economy, based on open systemic counteraction to any methods of shadow alienation of state-owned objects. The use of modern methods of privatization, namely the sale of shares of large stateowned enterprises in stock exchanges through the mechanism of IPO, fully complies with these requirements.

Article 16 of the Law of Ukraine on Privatization of State Property [20] concerns the direct sale of shares in international stock markets, the Law provides for the possibility of privatization by selling shares of stateowned enterprises on international stock exchanges. According to the State Property Fund in Ukraine, as of October 1, 2016, only $8.34 \%$ of the total privatized objects were privatized through the sale of shares in joint stock companies. All objects were sold through national stock exchanges, not using the opportunities of international capital markets. In 2016, the State Property Fund of Ukraine sold the state bank Ukrainian Bank for Reconstruction and Development to Chinese investor Bohai Commodity Exchange Co., Ltd. (BOCE) for UAH 82,827 million [18]. There is some separate information about certain objects sold to foreign investors in Ukraine, but there is no consolidated statistics which part of privatization proceeds can be considered foreign investments. The reflection of such statistics would increase the transparency of privatization processes.
Table 2. Dynamics of inflows of FDI to Ukraine for 2010-2016.

\begin{tabular}{ll}
\hline year & FDI (mln. USD \\
\hline 2010 & 5851,2 \\
2011 & 6033,7 \\
2012 & 5290,7 \\
2013 & 5462,1 \\
2014 & 2451,7 \\
2015 & 3763,7 \\
2016 & 4405,8 \\
\hline
\end{tabular}

Source: [19].

Because of the acute shortage of financial resources in Ukraine, private companies more actively use stock market instruments to attract investment. Private Ukrainian companies are actively placing securities on foreign stock exchanges. Among Ukrainian companies the most popular are the exchanges of Warsaw, Frankfurt, and less London because of the higher cost of securities placement. The first company listed on the foreign stock exchange was Ukrrichflot, a former state-owned company, which was privatized in 1992. Its shares were listed on the Vienna Stock Exchange in August 1998.

Institutionally-developed domestic stock market contributes to the effective sale of state-owned enterprises. Insufficient development of the internal stock market complicates this process. The stock market in Ukraine is characterized by a low level of liquidity and low level of infrastructure development and considered to be the least developed (frontier market). The problems of the Ukrainian stock market include underdeveloped infrastructure, inadequate level of protection of investors' rights, noncompliance of the stock market with generally accepted world standards and customs, complex and ineffective regulatory system, insufficient number of financial instruments with a focus on the short to medium term and a low level of liquidity in general. Also, entry barriers create significant problems for foreign investors. That is why it is necessary to consider the possibilities of the state companies to enter international capital markets in order to attract investments for the long-term period.

As there are more instruments for the influence of regulatory institutions on national investors, there is a perception that it is better to encourage domestic investors in the case of the sale of objects important for the national economy. However, in this context, it is very difficult to prevent the transformation of privatization of state-owned enterprises into a corruption mechanism for the distribution of state property between private companies that are close to authority.

\subsection{Peculiarities and Latest Examples of SOE`s IPO for Privatization Needs}

Initial public offering of securities is one of the effective mechanisms for attracting long-term investment capital for an enterprise. The IPO serves to stimulate economic growth 
by attracting foreign direct investment into the economy, as well as contributing to the restructuring of the economy by attracting long-term capital into the real economy.

In this study IPO of public sector entities is considered as a means of attracting foreign direct investments to the real sector of the economy. The main difference from the IPO of private companies is that the decision can be motivated sometime by noncommercial reasons, whether the state seeks to fully-privatise or if it plans to retain mixed-ownership. It should be emphasized that SOEs are characterized by the presence of a significant impact of non-profit motives in decisions making process regarding the timing of market entry and the amount of future emissions. Unlike private sector emissions, listing of state-owned companies may provide certain privileges for domestic investors, employees and citizens. In the public offerings priority to buy shares can be given to employees and to local individual investors through mechanism of early access or preferential share allocations. In the case of the sale of strategic companies' shares, the government always sets limits on the number of securities put up for sale and sets requirements for investors. Finding a balance between commercial and non-commercial goals of the company is quite difficult. Companies that have listed and placed their shares on the stock market must align the two opposite in their content goals. On the one hand, it is the maximization of shareholders' profits, the growth of the company's value, and the interest of private shareholders, which are usually minority shareholders. On the other hand, it is the achievement of certain social goals assigned to the company by the government.

The Organisation for Economic Co-operation and Development (OECD) experts consider the procedure of listing of state-owned enterprises as a means to improve corporate governance. It can serve to raise governance standards and improve company performance. The importance of maintaining a separation between the State's roles as shareholder, policy-maker and regulator is emphasized in OECD Report 2016. The report stipulates that each country has specific historical, economic, political and financial factors that influence the decision of the government about public offering of shares on the stock exchange [21].

Listing on a stock exchange means that the company becomes public. It is clear that the fact of listing state company`s shares does not automatically mean improving the quality of corporate governance, but will significantly contribute to this. One of the consequences of that will be the improvement of management standards. After all, the professional top management chosen by competitive selection, and not by the government, for example, for political reasons, will allow managing the company more qualitatively, protecting the interests of all shareholders. Protecting the rights of minority shareholders in case of participation in the capital of a state corporation is usually one of the important factors determining the investment climate in the country. Undoubtedly, the benefits of listing requirements in the stock market include increasing transparency of the company's operations, harmonizing accounting standards in accordance with international standards, which is facilitated by regular external audit. Due to the practice of information disclosure the opportunities for the corrupt component disappear.

IPO is actively used by developed countries for privatization purposes of state-owned companies. IPO of state-owned companies is seen as a first step towards a full privatization. The practice shows that large SOEs are usually privatised through listing rather than trade-sales. The mechanism of issuing and selling shares on a public stock market is one of the main forms of privatization around the world since the 1980s. Privatization through widely distributed public share offerings has been carried in developed countries. Developing countries and transition economies began to implement IPO of SOEs much later in comparison with developed countries.

OESD experts identify the following incentives for IPO of state enterprises on the stock markets: performance improvements through market discipline; capital market development and strengthen of local stock market; maximization of privatization revenue; attracting of financial resources for SOEs; improvement of efficiency and transparency of SOEs; freeing SOEs from public spending limits; raise of governance standards; encourage citizen investment in stock market [21].

A lot of publicly listed companies are partly state-owned companies with maintained effective control by state even without state being a majority owner. According to the OECD report, the share of state-owned companies in 2014 was about 13 percent of global market capitalization [21].

A characteristic feature of the IPO market in 2015 was the active privatization through primary public placement. During analyse of top 10 of IPOs in the world in 2015 we should emphasize that five of them were IPOs conducted for the purpose of privatization. In the first place among the largest IPOs in the world in 2015 was the placement of shares for the purpose of privatization of Japan Post Holdings, which attracted 5.179 billion euros on the Tokyo Stock Exchange. In second place among the largest IPO in the world was the privatization of Japan Post Bank on the Tokyo Stock Exchange (4.411 billion euros). Among the five largest placements in Europe, three were held by state-owned companies for privatization purposes - Aena at Bolsa de Madrid (BME) attracted 4.262 billion euros (fourth in the world), ABN AMRO in Euronext Amsterdam - 3.838 billion euros (fifth in the world) and Poste Italiane at Borsa Italiana 3.112 billion euros (seventh position among the top 10 IPOs in the world) [22]. Generally, in 2015 among the 10 largest IPOs in the world with the total cost of 35.469 billion euros, $58.7 \%$ accounted for privatization. Figure 1 shows the share of placements associated with the privatization of stateowned companies in the top 10 IPOs in the world in 2015 and 2016. 

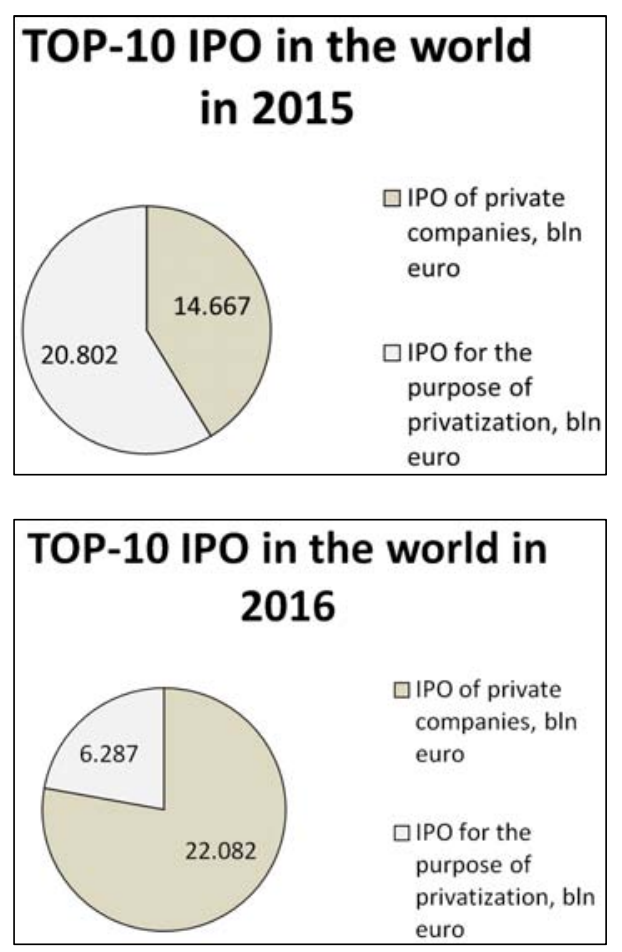

Source: compiled by the author using [22], [23].

Figure 1. The share of private companies and state-owned in TOP-10 IPOs in the world in 2015 and in 2016.

Recently the volumes of IPO in the world have decreased, taking into account the general tendencies on the international financial markets. In 2016, among the top 10 IPOs in the world on the first place was placement of JR Kyushu for the purpose of privatization on the Tokyo Stock Exchange and attracted 3.640 billion euros. In addition, Dong Energy A / S is privatized by IPOs on the NasdaqNordic Exchange (2.647 billion euros) [23].

The latest global financial crisis has led to certain shifts on financial markets. Changeable external conditions of international financial markets and features of modernized institutional system of international finance should be taken into consideration during development of an effective system of public finance management in terms of regulating the privatization process in Ukraine.

\subsection{Proposals for Improvement of Large State-Owned Enterprises's Privatization Processes in Ukraine Through IPO Mechanism}

The listing procedure on stock exchanges allows for transparent privatization and, at the same time, raising corporate reporting standards in state-owned enterprises. The status of a public company will achieve the important goals of transparency, avoidance of political influence and help to formulate the company's clear goals, which can be a powerful incentive to improve the management, monitoring and more effective use of property rights. Measures for reducing information asymmetry will reduce the information gap between investors and recipients, and promote the effective privatization.
Despite the world trends of strengthening regulation on financial markets in Ukraine there is a need to implement liberal arrangements for access of investors with the aim of attracting foreign capital. But in that case the prerequisite is the introducing of regulatory system for evaluation and supervision of compliance with the terms of contractual arrangements during corporatization of state-owned enterprises. We emphasize that the mechanism of stateowned enterprise's entering international financial markets should be based on principles of upholding national interests; but at the same time it should combine the elements of investor protection in order to increase the attractiveness of investment objects.

A detailed analysis of stock exchanges makes it possible to highlight the actual for Ukraine platforms for the placement of shares of companies belonging to the public sector. For sure, listing on leading world stock exchanges for Ukrainian state-owned companies is not yet appropriate because of the strict quantitative and qualitative requirements. But, for the example the Warsaw market is extremely interesting for Ukraine in terms of a simplified listing procedure as well as convenient location. Besides it should be noted that the Warsaw Stock Exchange is among the ten most active markets for IPO in Europe.

Also interesting for Ukraine are stock markets of the Baltic countries which are united into the single Baltic market created to minimize the barriers of the Estonian, Latvian and Lithuanian stock markets and belong to the Swedish-Finnish OMX company. Together, the Tallinn Stock Exchange, the Stockholm Stock Exchange, Helsinki, Riga and Vilnius are part of the NASDAQ OMX stock exchange. These platforms are also relevant for Ukrainian companies in case of signing of simplified listing agreements with the support of the international donors.

Taking into account the significant support of Sweden's programs in the field of public finance development in Ukraine, the possibility of the using SIX Swiss Exchange and Nasdaq Stockholm as the platforms for the exit of Ukrainian state-owned enterprises for the purpose of privatization should be taking into consideration. The choice of permanent platforms for initial placements for privatization depends to a large extent on cooperation with the international financial institutions (IFI) and their assistance in organizing a simplified listing procedure.

However, a promising direction is the structuring of Ukrainian enterprises by industry. For example we propose placing of the enterprises belonging to the sector of housing and communal services, infrastructure on the markets of Sweden, in Denmark - energy sector, in Warsaw - agrarian companies and light industry. Agriculture businesses are also extremely interesting for Asian markets; China stock exchanges are especially worthwhile in this context. Energy sector is interesting for platforms in Norway or Warsaw.

In order to provide financial and legal support for the listing procedure, the issuer should have highly qualified employees to reduce the risk of breaking an IPO due to noncompliance with the securities market legislation at the stage 
of preparation of documents and registration of release, or due to lack of market demand for securities. For effective placement of securities on foreign platforms, Ukrainian companies need the professional assistance. Cooperation with underwriters is an important element in the strategy of entering the market. IFIs can help to establish cooperation with stock exchanges and along with carrying out advisory functions, can also act as a strategic partner during the privatization of large state-owned enterprises through IPO in international capital markets. Also IFIs can act as a donor, partially covering production costs, including fees for legal support and auditing of the issuer.

Serious problem that faces the effective attraction of funds on foreign exchanges for Ukrainian companies is the lack of market demand for securities. A financial intermediary can also help to resolve this problem. IFI's strategic participation in the process of allocation of IPO for transparent privatization and attracting foreign investors can be provided by issues of special financial guarantees for underwriter that would offset the risks of being placed under the "firm commitment" scheme. Then in case of insufficient demand for shares, the underwriter will receive compensation from the IFIs for the size of the delta between the price of the issuer and the price at which the assets will in fact be sold to investors. The mechanism is described on Figure 2.

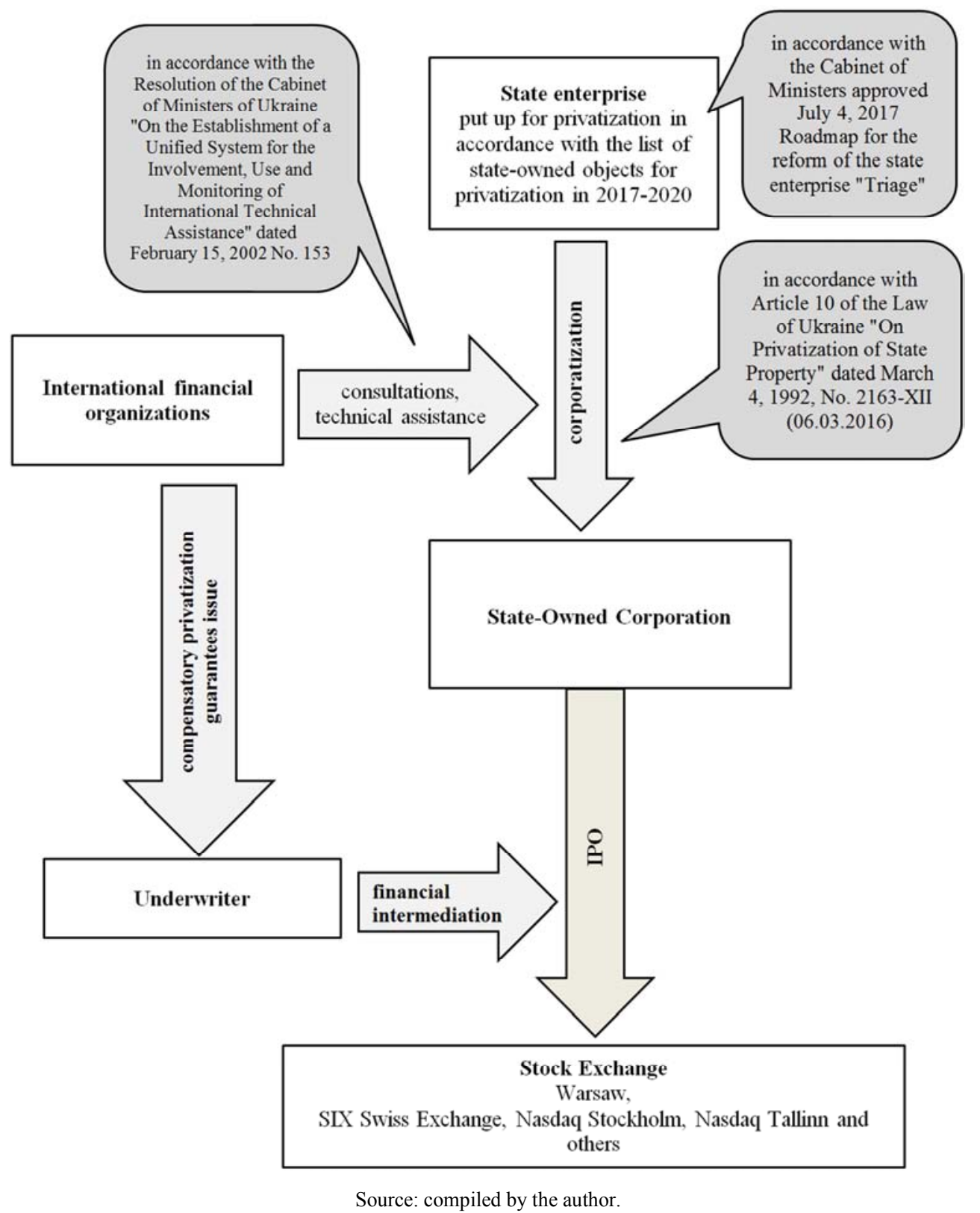

Figure 2. Mechanism of strategic participation of IFIs in the privatization of large state-owned enterprises through IPO.

A permanent platform for implementing IPO with simplified access to the listing procedure after prior consultation and coordination with international donors, which would provide special financial compensation guarantees to underwriters for the privatization of Ukrainian large state-owned enterprises, would significantly simplify 
the mechanisms for entering the foreign financial markets and facilitate transparent privatization, which meets the terms of the IMF Memorandum.

\section{Conclusion}

Changeable external conditions of international financial markets and features of modernized institutional system of international finance should be taken into consideration during development of an effective system of public finance management in terms of regulating the privatization process. The institutional environment of international finance is heterogeneous and this must be considered when developing strategies for state-owned entities going public. The latest global financial crisis has led to certain shifts on financial markets. The volume of speculative capital decreased slightly due to the strengthening of regulation on international capital markets. So providing the state guarantees in exchange for capital and technology can be a good opportunity to attract looking for the lowest risk investors. The development of the institutional environment is an important element in the system of attraction of investments into the country, and provision of additional guarantee of investment projects will contribute to the flow of capital. We emphasized the importance of conducting IPOs in Ukraine as an instrument of attraction investment on the international financial markets. The practical recommendations for implementing the mechanism of strategic participation of international financial organizations in the privatization of large stateowned enterprises through primary public offerings are presented. The importance of the international donors' assistance in support of privatization programs in Ukraine is emphasized. It is noted that in order to carry out transparent privatization successfully and to attract foreign investments in the international financial markets it is expedient, together with international donors, to develop mechanisms for simplified access to the stock markets of state-owned companies which are subject to privatization, but do not meet the strict listing conditions. It is proposed the list of stock exchanges appropriate for IPO of state-owned companies in case of signing the Memorandums on a simplified listing mechanism. In the article the mechanism for granting privatization compensatory guarantees to underwriters by international financial organizations is proposed. Such guarantees will support the successful IPO of companies that are in state ownership and are subject to privatization.

\section{References}

[1] Curtis J. Milhaupt, Mariana Pargendler (2017). Governance Challenges of Listed State-Owned Enterprises around the World: National Experiences and a Framework for Reform. ECGI Working Paper Series in Law, 352.

[2] Curtis J. Milhaupt, Wentong Zheng (2016). Why MixedOwnership Reforms Cannot Fix China's State Sector. Paulson Policy Memorandum.
[3] Corporatization and Privatization of the Government (2016). Sovereignty Education and Defense Ministry (SEDM).

[4] Sol Trumbo Vila, Matthijs Peters (2016). The Privatisation Industry in Europe. Transnational Institute, Amsterdam.

[5] Krugman P. (1996). The self-organizing economy. WileyBlackwell.

[6] Krugman P. (2010). The new economic geography, now middle-aged. Regional Studies, 45 (1), 1-7.

[7] Shapiro C., Willig R. D. (1990). Economic rationales for the scope of privatization. The Political Economy of the Public Sector Reform and Privatization (Suleiman, E. N., Waterbury, J.), Westview Press, Boulder, CO, pp. 55-87.

[8] Bortolotti B., Faccio M. (2004). Reluctant Privatization. EGGI Working Paper, 4.

[9] Swee-Sum Lam, Ruth Seow-Kuan Tan, Glenn Tsao-Min Wee (2007). Initial Public Offerings of State-Owned Enterprises: An International Study of Policy Risk. Journal of Financial and Quantitative Analysis, 42 (2), 313-337.

[10] Fisman, R. (2001). Estimating the Value of Political Connections. American Economic Review, 91, 1095-1102.

[11] Faccio Mara, Ronald W. Masulis, John J. McConnell (2006). Political Connections and Corporate Bailouts. Journal of Finance, 61, 2597-2635.

[12] Villalonga, B. (2000). Privatization and efficiency: differentiating ownership effects from political, organizational, and dynamic effect. Journal of Economic Behavior \& Organization, 42 (1), 43-77.

[13] Wang, X., Xu, L. C. and Zhu, T. (2004). State-owned enterprises going public, The case of China. Economics of Transition, 12, 467-487.

[14] Ukraine: Letter of Intent, Memorandum of Economic and Financial Policies (2017). International Monetary Fund, March 02.

[15] Roadmap "Triage" for the reform of the state-owned enterprises sector. (2017). Ministry of Economic Development and Trade of Ukraine, July 4, 2017.

[16] Brian Olden, Dimitar Radev, Kris Kauffmann, Dag Dette (2016). Ukraine: Technical Assistance Report - Public financial management overview. IMF Country Report, 16/30.

[17] Report on the work of the State Property Fund of Ukraine in 2016 (2016). The State Property Fund of Ukraine.

[18] Statistical data. The State Property Fund in Ukraine.

[19] State Statistics Service of Ukraine.

[20] The Law of Ukraine On Privatization of State Property (1992). Verkhovna Rada of Ukraine, 24, 348.

[21] OECD (2016). Broadening the Ownership of State-Owned Enterprises: A Comparison of Governance Practices. OECD Publishing, Paris.

[22] IPO Watch Europe 2015. (2016). PricewaterhouseCoopers LLP Outlook.

[23] IPO Watch Europe 2016. (2017). PricewaterhouseCoopers LLP Outlook. 